\title{
Characteristics of Household Waste Management in an Effort to the Achievement of Sustainable Development Goals (SDGs) in Krembangan District of Surabaya City
}

\author{
Abdul Wahid Arfanto ${ }^{1}$, F. RooslanEdySantosa ${ }^{2}$ \\ Narotama University, Surabaya \\ arfantoo@gmail.com
}

\begin{abstract}
Sustainable Development Goals (SDGs) is a continuous development program which 17 destinations.This research was conducted in District Krembangan Surabaya, the goal is to determine the level of knowledge, attitudes and behavior of public in waste management activities and the role of government in waste management activities. The determination of the respondents were selected by a procedure in the Study of Environmental Health Risk Assessment (EHRA). The data obtained from interviews and observations will be entered into the software EHRA, then processed using Microsoft Excel. The results of this study include the management of household waste, the frequency and accuracy of transporting waste and waste sorting activities. $89 \%$ of respondents are already carrying out waste management by means of collected and discharged intotemporary landfill. Waste hauling was done in a regular frequency, as much as $14 \%$ respoden have done sorting waste at home before being dumped intotemporary landfill.
\end{abstract}

Keywords: Waste Management, SDGs, EHRA

\section{INTRODUCTION}

The problem of waste management is one thing that should be considered by the public and the government. This problem has been one of the factors that may hinder the development of a city. Indonesia was in the order of the 2 nd as a contributor to the world's largest garbage that pollute the oceans after China (Hoegh-Guldberg et al., 2015). According to a report of the Ministry of the environment (2008), most of the trash in indoesiabe: $58 \%$ of organic waste, plastic waste, $14 \%$ and $9 \%$ of waste paper. From the above it can be reported that the percentage of the most solid waste comes from households.

Waste is material that has no value or no value to the regular or main intent (Astriani, 2009). While according to the definition of the WHO (World Health Organization) trash is something that is not being used, not used, not tolerated, or something dumped that comes from human activities and does not happen by itself. Household garbage is garbage generated by one or more families living in a dormitory building or in the village or town (Chandra, 2007). Waste management is the treatment of waste which aims to minimize or eliminate the problems relating to the environment (Azwar, 1990).

Sustainable Development Goals(SDGs) is a sustainable development program in which there are 17 goals with measurable targets to 169 with the time limits prescribed. SDGs is the world development agenda that aims to human well-being and the planet Earth. SDGs taggal is published on October 21, 2015 replaces the previous programmes, namely Millennium Development Goals (MDGs) as a shared development goals until the year 2030 which was agreed by the various countries in the Un resolution forum Nations (Un).

The research was based on regulation the Republic of Indonesia Number 18-year 2008 about waste management and the regulation of Surabaya citynumber 5-Year 2014 about waste management and the cleanliness of the Surabaya city. This research aims to find out the level of knowledge, attitudes, and

40

Characteristics of Household Waste Management in an Effort to the Achievement of Sustainable Development Goals (SDGs) in Krembangan District of Surabaya City

Abdul Wahid Arfanto, F. Rooslan Edy Santosa 


\section{Volume 1 Number 1 March 2018}

behaviour of public in the household waste management activities and the important role of the Government in conducting household waste management.

\section{RESEARCH METHODS}

This research uses descriptive research approach. Precisely using qualitative descriptive study, because the researchers intend to describe descriptively on household waste management activities in the Krembangan district, Surabaya city. The data collection was done by interview and observation using a questionnaire EHRA Studies.

\section{Sampling techniques}

The sampling technique used in this research is a Random Sample, with random technique combines multistage random and systematic. The sampling technique aims to get a representative sample, representative samples are samples that have the same characteristics or traits are relatively similar to the characteristic features of the population.

Determination of the respondents selected by procedures specified in the study of EHRA. Where in each village will be taken 8 household (RT) in random order, in each RT would have taken five residents as respondents.

In determining the minimum sample size of respondents can use the "Formulas Slovin". This formula is used to determine an estimate of the proportion of the population using the sample proportion. Here is a form of "Formula Slovin":

$n \frac{\mathrm{N}}{N \cdot d^{2}+1}$

Known :

Total of population $(\mathrm{N})=127564$ (BPS Surabaya, 2017)

Standard Deviation $(\mathrm{d})=10 \%(0.1)$

thus:

$$
\begin{aligned}
& n=\frac{\mathrm{N}}{N \times d^{2}+1}=\frac{127.564}{127.564 \times 0,1^{2}+1}=\frac{127.564}{1.275,64+1} \frac{127.564}{1.276,64} \\
& =99.907
\end{aligned}
$$

\section{Processing Techniques}

Data processing on this research will use some software. Data input will be performed using software EHRA, then the data will be submitted to the Health Department of Surabaya. Then the data will convert first, and then will be processed using Microsoft Excel.

\section{RESULTS AND DISCUSSION}

\section{Household or Respondent Characteristics}

Characteristics of Respondents in this study, described by age group, the status of occupied housing, education, certificate can not afford (SKTM), ownership of health insurance are cards for poor families (ASKESKIN), and possession of the child. Data on each variable above are presented in Table 1.

Table 1. Respondent information
\begin{tabular}{|l|l|c|c|}
\hline \multicolumn{2}{|c|}{ Information } & \multicolumn{3}{c|}{ Total } \\
\cline { 2 - 4 } & $\leq 20$ years & 0 & 0 \\
\hline \multirow{4}{*}{ Respondents Age Group } & $21-25$ years & 18 & 9 \\
\cline { 2 - 4 } & $26-30$ years & 21 & 10.5 \\
\cline { 2 - 4 } & $31-35$ years & 28 & 14 \\
\cline { 2 - 4 } & $36-40$ years & 28 & 14 \\
\hline
\end{tabular}


Volume 1 Number 1 March 2018

\begin{tabular}{|c|c|c|c|}
\hline & $41-45$ years & 31 & 15.5 \\
\hline & $>45$ years & 74 & 37 \\
\hline \multirow{5}{*}{$\begin{array}{l}\text { The status of the house } \\
\text { occupied by the } \\
\text { respondent }\end{array}$} & One's own & 136 & 68 \\
\hline & Official residence & 0 & 0 \\
\hline & lease & 5 & 2.5 \\
\hline & Contract & 24 & 12 \\
\hline & $\begin{array}{l}\text { Belongs to the } \\
\text { parents }\end{array}$ & 35 & 17.5 \\
\hline \multirow{6}{*}{$\begin{array}{l}\text { Last Education } \\
\text { respondents }\end{array}$} & $\begin{array}{l}\text { No formal } \\
\text { schooling }\end{array}$ & 0 & 0 \\
\hline & $\mathrm{SD}$ & 30 & 15 \\
\hline & SMP & 30 & 15 \\
\hline & SMA & 90 & 45 \\
\hline & SMK & 14 & 7 \\
\hline & $\begin{array}{l}\text { University / } \\
\text { Academy }\end{array}$ & 36 & 18 \\
\hline \multirow{2}{*}{$\begin{array}{l}\text { Respondents who have a } \\
\text { Certificate of No Able } \\
\text { (SKTM) from the village / } \\
\text { village }\end{array}$} & Yes & 9 & 4.5 \\
\hline & Not & 191 & 95.5 \\
\hline \multirow{2}{*}{$\begin{array}{l}\text { Respondents who have a } \\
\text { health insurance card for } \\
\text { Poor Families } \\
\text { (ASKESKIN) }\end{array}$} & Yes & 117 & 58.5 \\
\hline & Not & 83 & 41.5 \\
\hline \multirow{2}{*}{$\begin{array}{l}\text { Respondents who have a } \\
\text { child }\end{array}$} & Yes & 176 & 88 \\
\hline & Not & 24 & 12 \\
\hline
\end{tabular}

Source: Results (Data Processed)

The age group of respondents is presented in Table 1, is distributed in all age categories. Respondents in the age group $>45$ years showed the highest persentasae $37 \%$, followed by the age of $41-45$ years $15.5 \%$. While respondents with $\leq 25$ years of age category gives the lowest percentage of $9 \%$.

Respondents in this study mostly have the status of their own homes and at $68 \%$ of respondents stated that the status of the house belonging to the parents of $17.5 \%$. While $14.5 \%$ of respondents have a status that is not your own home. Respondents who occupy the house that does not possess tend to have a low sense of responsibility towards the environment, otherwise the respondents who have their own homes or belongs to the parents tend to have more of a sense of high responsibility towards cleanliness and health of the environment.

The level of education is a factor that will determine the knowledge, attitude and behavior towards the management of household waste. Respondents in this study most have a high school education level that is equal to $45 \%$, followed by respondents in the education level of university / Academy which is $18 \%$. This was followed by the respondent at the level of primary and secondary education, ie maisng amounted to $15 \%$. Respondents at the level of vocational education as much as $7 \%$, in this study there were no respondents with no formal school education level.

Respondents who have a Certificate of Disadvantaged in District Krembangan only $4.5 \%$, and respondents who have a Health Insurance for Poor Families (ASKESKIN) amounted to 58.5\%. This indicates that the level of local community economy is good enough, which is expected to have a positive impact on waste management and environmental health Kembangan Sub-district.

Information on respondents have children or not having children, meant to illustrate the magnitude of the population in Sub Krembangan. Most of the respondents of this study reported having a child at $88 \%$.

\section{Household Waste Management}

In this study obtained data related to the management of household waste, either through the interview method and observation method with respondents who aim to obtain the following information:

1. Household waste management 


\section{Volume 1 Number 1 March 2018}

2. Frequency and timeliness of transporting waste

3. sorting of waste

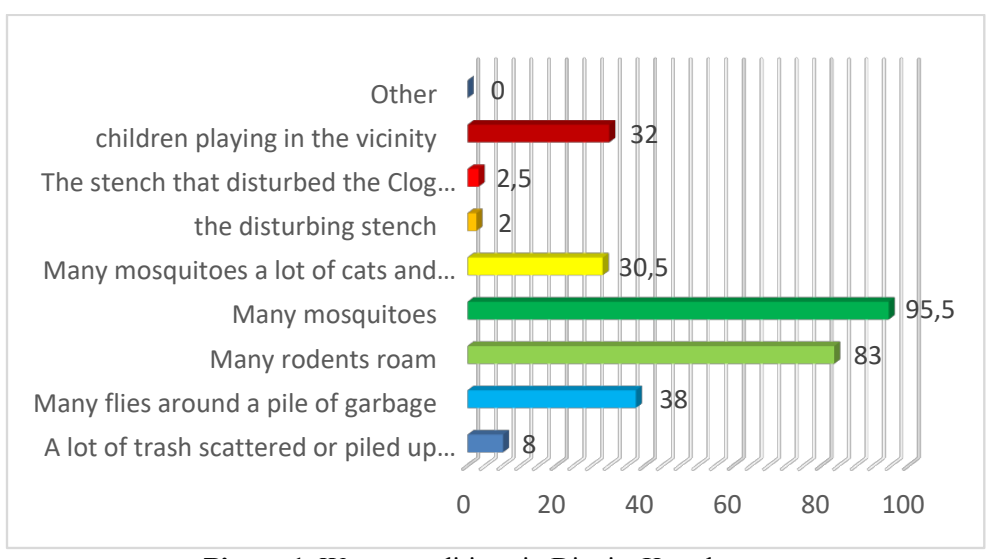

Picture1, Waste conditions in District Krembangan

The results in Figure 1 show that respondents who expressed much trash scattered or piled around the neighborhood only by $8 \% .38 \%$ stated that around trash still a lot of flies. Of $83 \%$ is still a lot of rats roaming around garbage. Of respondents stated that there are many mosquitoes around garbage by $95.5 \%$, and $30.5 \%$ said there are many cats that came to a pile of garbage, while $2 \%$ of respondents said they no foul odors. $2.5 \%$ of respondents said trash blocking drainage channels, and respondents who stated they kids playing around garbage by $32 \%$.

Conditions waste in the district Krembangan illustrates that the sense of responsibility of the local community is still low. This proves that the state variables house occupied by respondents may affect the environmental conditions. If more and more people who have not owned their own home status then it will be bad for the condition of waste in the environment, because respondents who occupy homes that are not owned by themselves tend to have a low sense of responsibility towards the environment.

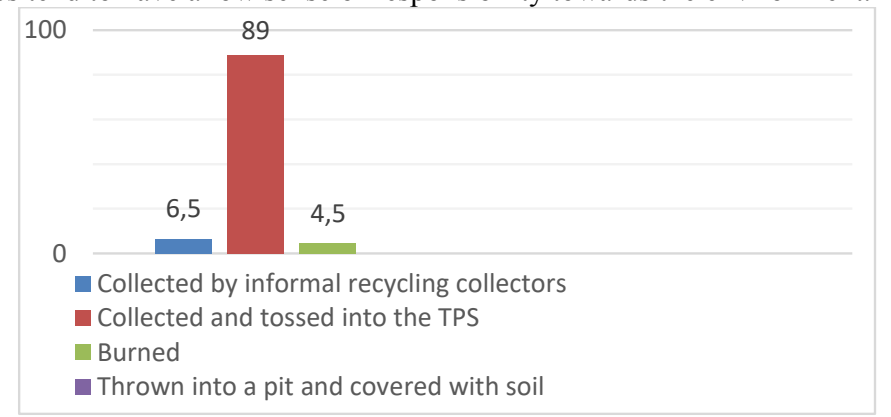

Picture2, Household Waste Management

Based on the data described in Figure 2, the respondents were already managing household waste collected and disposed in a way to the TPS by $89 \%$, while respondents who manages a way collected by informal collectors who recycle only $6.5 \%$ and amounted to $4,5 \%$ of respondents do waste management by burning. While waste management in a way thrown into the hole and covered with soil, dumped into the hole but not covered with earth, thrown into a river / times / sea / lake, left alone to rot and thrown into the vacant land / garden / forest and left to rot there is no community use in the District Krembangan Surabaya.

On the issue of household waste management, education level variables affects the waste management activities. District of Krembangan number of people who have education level above the level of secondary education, proves that the level of knowledge, attitudes and behavior of the local community towards the management of household waste collected and disposed of in a way to the polling station is as high as $89 \%$. This result is a pretty good achievement, because almost all the citizens of District Krembangan already have a high level of awareness on waste management and environmental health. 
Volume 1 Number 1 March 2018

Table 2. Frequency Garbage Trucks

\begin{tabular}{|l|c|c|c|c|c|c|c|}
\hline \multirow{2}{*}{ Information } & \multicolumn{6}{c|}{ Village / Sub-District } & Total \\
\cline { 3 - 7 } \multicolumn{2}{|c|}{} & Dupak & Kemayoran & $\begin{array}{c}\text { Krembangan } \\
\text { Selatan }\end{array}$ & Morokrembangan & $\begin{array}{c}\text { Perak } \\
\text { Barat }\end{array}$ & $\mathrm{n}$ \\
\cline { 3 - 7 } & $\mathrm{n}$ & $\mathrm{n}$ & $\mathrm{n}$ & $\mathrm{n}$ & $\mathrm{n}$ & \\
\hline $\begin{array}{l}\text { How often } \\
\text { attendant } \\
\text { transport } \\
\text { garbage from } \\
\text { home? }\end{array}$ & $\begin{array}{c}\text { Every } \\
\text { day }\end{array}$ & 10 & 5 & 15 & 10 & 0 & 40 \\
\cline { 2 - 7 } & $\begin{array}{c}\text { Several } \\
\text { times a } \\
\text { week }\end{array}$ & 30 & 35 & 25 & 30 & 40 & 160 \\
\hline
\end{tabular}

Source: Results (Data Processed)

In the resulting data is shown in Table 2 above shows that the waste transportation in the District Krembangan done regularly two to three days or even every day. Of respondents stated that the garbage is transported every day by the clerk by $20 \%$, while the respondents stated that waste is transported several times a week by $80 \%$. Krembangan waste transportation in the district is good enough and does not cause problems.

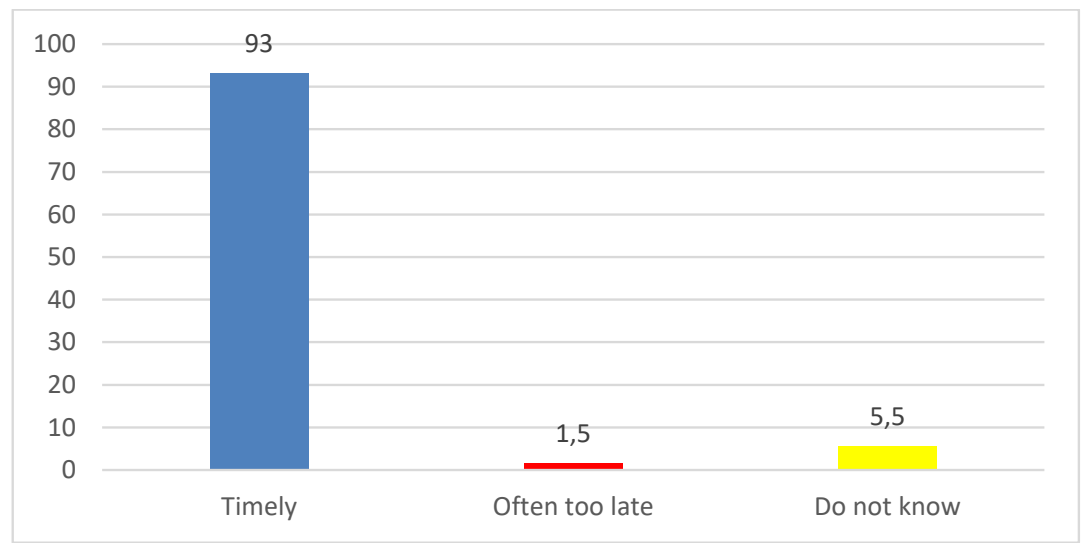

Picture3, Accuracy of Garbage Trucks

Timeliness of waste transportation is a very important factor in hygiene and environmental health. Delays in transporting waste can cause a buildup of trash, so it can have a negative impact on the hygiene and environmental health. Most of transporting waste by the clerk made on time, ie by $93 \%$. Of respondents stated that waste transport is often too late by $1.5 \%$ and the respondents stated not know as much as $5.5 \%$ as shown in Figure 3 respondents stated not know for transporting waste carried out in the early morning when most respondents were activities outside the home. Frequency and timeliness of transporting waste in the District Krembangan is good enough, coordinated and can reduce the level of environmental health risks.

Activity sorting of waste prior to disposal is one form of waste reduction. Sorting of waste has the purpose of avoiding the drop in the value of goods that can still be used and to minimize the number and composition of waste. 


\section{Volume 1 Number 1 March 2018}

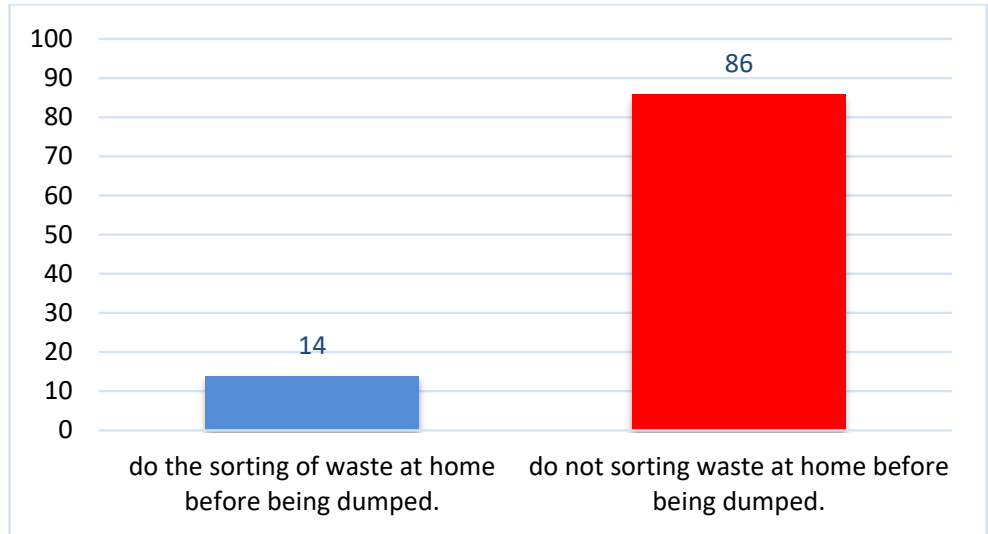

Picture 4, Waste Sorting Activities at Home Before Removed

Figure 4 above shows that respondents who expressed no sorting garbage by $86 \%$, while respondents who pick through the trash before it is disposed only at $14 \%$. This indicates that the low participation of citizens in the sorting of waste, low participation of citizens also demonstrated that low awareness of local communities on waste management and environmental health around. The low level of public knowledge about the importance of the District Krembangan waste management is one factor low community participation in waste sorting activities and the lack of government's role in education in the District Krembangan waste sorting. In Figure 5 a waste sorting will be described in detail, how respondents sort domestic waste before disposal.

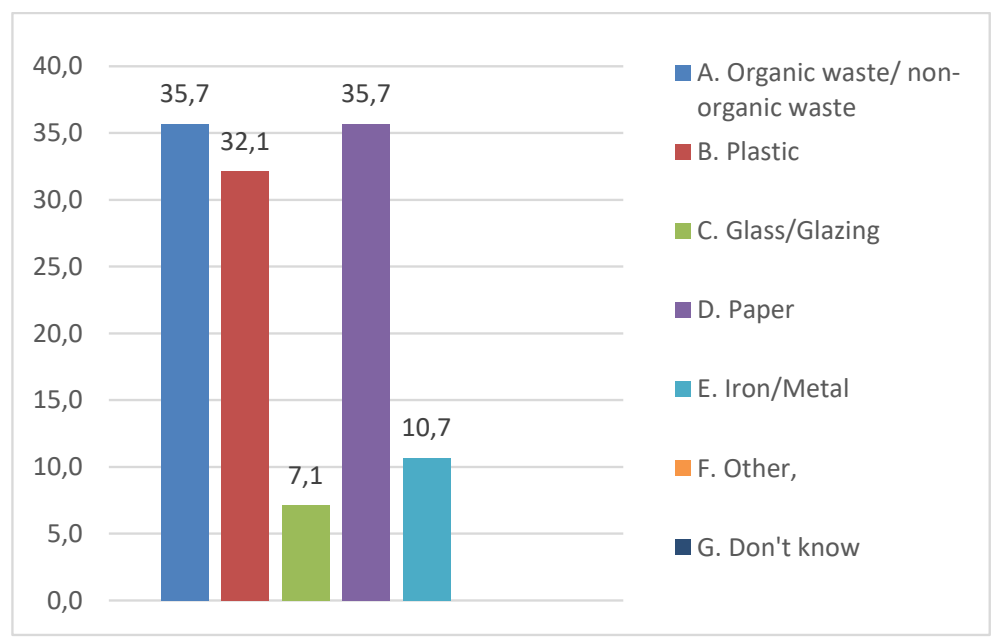

Picture 5, Trash The disaggregated Before Removed

As shown in Figure 5 above, that the respondents who started separating organic waste / wet garbage $35.7 \%, 32.1 \%$ of respondents do the sorting of waste in the form of plastic. Respondents who pick through the trash in the form of a glass / glass at 7.1\%. Respondents who pick through the trash in the form of paper amounted to $35.7 \%$ and respondents who pick through the trash of an iron / metal of $10.7 \%$.

Variable education level had no effect on waste sorting activities. This can be evidenced by the low level of public knowledge about the activities of sorting, although data on education level variables showed excellent results. 


\section{Volume 1 Number 1 March 2018}

\section{CONCLUSION}

Based on the results and discussion of the research studies EHRA above, it was concluded as follows:

1. The majority of the community Sub-district Krembangan already doing household waste management in a way gathered and thrown into the TPS, is about $89 \%$ (as much as 178 of 200 respondents). It can be inferred that the public and the Government was aware of the importance of household waste management is good and true, although there are still some people who still do household waste management by burning it.

2. Transporting waste has been carried out in a regular frequency every two to three days or even every day, timeliness of transporting waste has also been quite good. This will be good for hygiene and health of the surrounding environment, thus showing the process of transporting waste has been good enough, coordinated and reduce environmental health risks.

3. Low community participation that only $14 \%$ of the 200 respondents to the waste sorting activities, this shows that the Government has not been optimal in a extension sorting the waste.

\section{REFERENCES}

Astriani, 2009.DampakSampahTerhadapLingkungandanMakhlukHidup.Jakarta.

Dewi, S., \& Warmadewanthi, I. (2010). KAJIAN MODEL PENGELOLAAN SAMPAH BERBASIS MASYARAKAT DI KECAMATAN WONOCOLO.

Dinas Kesehatan Kota Surabaya. Laporan Akhir Studi EHRA Kota Surabaya Tahun 2015, No. 197. Jalan Jemursari. Surabaya.

Hadiyarto, A., \& Diponegoro, U. (2015). Pengelolaan sampah rumah tangga di kecamatan daha selatan, (January 2011).

Hoegh-Guldberg, O., Cai, R., Poloczanska, E. S., Brewer, P. G., Sundby, S., Hilmi, K., ... Jung, S. (2015). The ocean. Climate Change 2014: Impacts, Adaptation and Vulnerability: Part B: Regional Aspects: Working Group II Contribution to the Fifth Assessment Report of the Intergovernmental Panel on Climate Change, (January), 1655-1734.

Kabupaten, D. I., Tahun, K., Ehra, S., \& Email, S. (2016). No Title, 1-14.

Kota Surabaya. Peraturan Daerah No. 5 Tahun 2014 tentang Pengelolaan Sampah dan Kebersihan di Kota Surabaya. Lembaran Daerah Kota Surabaya Tahun 2014, No.5. Sekretaris daerah Kota Surabaya. Surabaya.

Raharjo, S. T. R. I. (2014). Article Detail - Center for Indonesia's Strategic Development Initiatives. ICN (International Council Nursing) Dan PPNI, 0042, 159-167.

Republik Indonesia. Undang-Undang No. 18 Tahun 2008 tentang Pengelolaan Sampah. Lembaran Negara RI Tahun 2008, No. 69. Sekretariat Negara. Jakarta.

Republik Indonesia. Undang-Undang No. 81 Tahun 2012 tentang Pengelolaan Sampah Rumah Tangga dan Sampah Sejenis Sampah Rumah Tangga. Lembaran Negara RI Tahun 2012, No. 188. Sekretariat Negara. Jakarta.

Rumah, S., Di, T., \& Bengkulu, K. (2015). Karakteristik penanganan sampah rumah tangga di kota bengkulu, 24-31.

SNI 19-3242-1994. Sampah di Pemukiman, Tata Cara Pengelolaan. Jakarta : Badan Standardidasi Nasional.

Soedjono, Wibowo, SaraswatidanKeetelaar. 2010. BukuReferensiOpsiSistemdanTeknologiSanitasi.Jakarta

: Tim Teknis Pembangunan Sanitasi (TTPS).

http://www.sanitasi.or.id/?p=709diaksespadatanggal 31 oktober 2018.pukul 00.52

http://sipsn.menlhk.go.id/?q=3a-data-

umum\&field_f_wilayah_tid $=1519 \&$ field_kat_kota_tid=All\&field_periode_id_tid $=2168$ diaksespadatangg al 31 oktober 2018 .pukul 22.52

http://www.usdp.or.id/id/?page_id=4543diaksespadatanggal 1 november 2018. pukul 23.27 